DOI https://doi.org/10.36059/978-966-397-174-2/43-62

\title{
TERMINOLOGICAL AND PROGNOSTIC ISSUES OF HUMANIZATION OF PEDAGOGICAL ACTIVITY OF TEACHERS OF HIGHER EDUCATION INSTITUTIONS OF UKRAINE IN THE CONTEXT OF EUROPEAN INTEGRATION
}

\section{Sushchenko A. V., Dariush Skalski}

\section{INTRODUCTION}

At the end of the 10th years of the XXI century the public institutes of Ukraine emphasized the urgency and necessity of realization of the principle of humanism in all spheres of human activity. This process has been revitalized after making political decisions aimed at integration of Ukraine into the European community, which proclaims a person, its life, health, honor, dignity, integrity and security the highest social value. By its content, this movement qualitatively broadens the space for freedom of each individual, becomes an important factor in optimizing the activity of the educational sphere of Ukraine, approaching the time when the humanistic standards of pedagogical work in general, and the scientific and pedagogical activity of teachers of higher education institutions in particular, will be approved.

The aspirations of professional educators able to understand and realize the peculiarities of this orientation in the European Union have been reflected in the Law of Ukraine „On Education"1 and "On Higher Education", National Strategy for the Development of Education in Ukraine until $2021^{3}$, Concept of realization of state policy in the sphere of reforming of general secondary education „New Ukrainian School” for the period until 2029 and other official state documents.

1 Закон України «Про освіту». Відомості Верховної Ради (ВВР). 2017. № 38-39. с. 380. https://zakon.rada.gov.ua/laws/show/2145-19

2 Закон України «Про Вищу освіту»https://zakon.rada.gov.ua/laws/show/1556-18

3 Національній стратегії розвитку освіти в Україні на період до 2021 року [Електронний ресурс]. - Режим доступу: https://zakon2.rada.gov.ua/laws/show/344/ 2013/page 
The tasks identified in these documents require solving a number of scientific and practical problems, one of which is the problem of humanization of the pedagogical activity of teachers of higher education institutions. The state of its development in education indicates the presence of a number of contradictions, in particular between:

- the global need for humanization of all spheres of human life and the local lobbying of economic development priorities over the spiritual one;

- the modern, generally accepted view of the effects of a personcentered environment and an authoritarian, depersonalized tradition of fulfilling professional responsibilities by teachers of higher education institutions;

- the long-term formation of a teacher-humanist and the rapid leveling of his socio-economic status by the state and a higher education institution;

- the ideas of humanism about equality of living conditions, justice and brotherhood in a democratic society and the low socio-economic competitiveness of a teacher of a higher education institution;

- the rapid development of requirements to the level of teaching awareness in the field of new knowledge and the inability to achieve fairness in assessing the quality of the implementation of their functions, etc.

Ensuring the humanization of pedagogical activity is further complicated by the fact that the knowledge which the teacher acquires in the course of his professional mission quickly loses its value and relevance. One-off acts of professional development and internship have almost lost their methodological value for a teacher, replacing personal training with practically tourist trips to the EU countries, which are ineffective, though useful from the point of view of psycho-emotional recovery and improvement.

The nature and significance of this problem has been considered by many researchers from different sides and has received numerous options and approaches to solving it. According to the analysis of scientific achievements, the preparation of teachers, which has a pronounced humanistic orientation, has a positive effect in solving many existing educational problems: establishing communication between the subjects of the pedagogical process, eliminating the leveling of social, religious, 
national inequality, protection of the rights of a teacher, etc. This approach opposes the manipulative effects of the technologized world, which are destructive for a teacher, - electronic communication, suggestive, psychotropic, etc., but one has to admit that in the mass practice of modern professional education its implementation has not achieved significant success.

This indicates an increase in the value of those works that reveal the mechanisms of assistance to a teacher of higher education institution in the implementation of systemic self-organization, the purpose of which is the movement to a more effective type of pedagogical activity, the dominant characteristic of which is the free expression of humanity in feelings, consciousness and will, regardless of any any long-term social problems or temporary local difficulties.

A critical analysis of the already known ways of solving the problem shows that the existing theoretical and methodological ideas about this phenomenon are mostly partial, conceptually uncoordinated, and often contradictory. Meanwhile, the humanization of pedagogical activity can be the universal resonant factor that will help to revive the existential meanings of the teaching profession of a teacher of universities and higher education institutions.

Our idea is based on the understanding of the humanization of pedagogical activity as the definition and approval by the teacher of higher education institution of such pedagogical position, which is based on the unconditional acceptance of the uniqueness of each person as the highest value, given that the teacher himself/herself should be of such value to all subjects.

These ideas are proposed to be implemented in the process of advanced training inside a higher education institution and further scientific support of the humanization process in the real practice of organizational, educational, scientific, methodical and educational work of teachers of higher education institutions. Such training should not be based on the regulated, manipulative influence of a person on a person, but on the personal desire of each teacher to independently realize in his/her profession the untapped humanistic potentials.

Creating a reflexive environment at the stage of cognition, awareness and self-determination of this potential is a prerequisite for the beginning 
of an organized process of humanization and positive changes in the personal values of the teacher, which can be an extremely cathartic event for him/her.

In this condition, the teacher needs facilitation (support), the source of which is carriers of successful experience of pedagogical activity on the basis of humanism.

The unpredictability of the actual results obtained for the teacher at the initial stage does not diminish the importance of the process of selfrealization of humanistic potentials in the chosen profession, the path to which lies through the implementation of personal values in the relevant motives of activity. Sufficient conditions are deduced from the characteristics of productivity and success of the activity itself of a teacher of a higher education institution.

Thus, the essence of the process of humanization consists in the active self-realization of the humanistic potential of a teacher, the affirmation of the value of his/her human existence in other people, the translation of real humanistic feelings (sincerity, kindness, empathy, etc.).

The purpose of this work is to highlight the terminological and prognostic issues of humanization of pedagogical activity of teachers of higher education institutions of Ukraine in the context of European integration.

\section{Analysis of terminological basis of research of humanization of pedagogical activity of teachers of higher education institutions}

Achieving this goal can be accomplished by answering a number of important questions, namely:

- under what conditions does the full fulfilment by a teacher of his humanistic potentials happen in the chosen profession?;

- how to transform personal and humanistic values into appropriate motives of pedagogical activity?;

- how to gain experience of humanistic pedagogical activity in universities that will open the way to free expression of humanity in feelings, thoughts and pedagogical actions?;

- how to build a pedagogical process in which the professional achievements of a teacher are based on spiritual interaction, 
psychological comfort, acceptance and empathy with another person, intellectual co-creation?

For many years, the author has personally participated in the development and implementation of the proposed theoretical and methodological recommendations and programs, carrying out teaching and research activities on the organization of continuous development of humanistic professional position at teachers of higher education institutions.

At the first stage of the research, one of the complex methodological problems was the definition of the terminological basis of the research, the formation of a reliable conceptual apparatus.

Preliminary analysis of the interpretations of the basic definitions of the general context of the humanization of pedagogical activity has proved that scientists offer a rather wide range of views on the definition of the basic concepts of the problem under study, arbitrarily interpreting them, which, of course, is unacceptable in science.

A clear articulation of the content and meaning of each term will allow to approach carefully to the development of the concept of humanization of pedagogical activity of teachers, to avoid meaningful and conceptual misunderstandings through clarification of the most commonly used conceptual constructs, namely: ,pedagogical activity on the basis of humanism", „humanization of pedagogical activity”, „educational process”, ,self-realization”, etc.

Noting that most of these definitions are not well established as specific scientific concepts, we consider it necessary to state our position concerning their use.

The most large-scale and multidimensional element of the main conceptual construct is ,humanism”.

In the history of mankind, there have been, and will be, various interpretations of humanism: national, or transnational, philosophical, general, and specifically scientific. They differ significantly in determining the place of a human in the world, the reason for its existence, the missiona ssigned to it. But they all agree on one thing - a human is the epicenter of the values of our world.

The analysis of the pedagogical, psychological and philosophical literature shows that this concept has many aspects and in each definition 
reflects one or the other side: humanism as value, humanism as a result, humanism as a system, humanism as influence on personality, humanism as a process. We consider and analyze the essence of humanism in view of the category of ,activity”. The validity of this approach is due not only to the fact that the object of our study is the pedagogical activity of teachers, but also that the activity itself acts as a basis, on which any person actively changes the world and creates itself. Being beyond an unambiguous definition, the word ,humanism" may include a set of meanings as follows:

- a way of living in the center of which stands a human;

- recognition of human life as the highest value;

- a human salvation program;

- self-actualization by a human of his own essence;

- model of understanding the human phenomenon;

- recognition of the high appreciation of human dignity;

- strategy of total domination of a human over the world, etc.

For further identification of the concept of ,pedagogical activity on the basis of humanism" let's turn to encyclopedic publications in the field of philosophy, pedagogy, psychology, political science, sociology, etc.

„Humanism (from the Latin. Humanus - human, humane) - a system of ideas and views on a human as the highest value"

Agreeing in general with S.U. Goncharenko regarding perceptions of a human as the highest value, let's clarify that a human can be the highest value only in comparison with other people, recognizing their rights to free development and manifestation of their abilities, affirmation of benefit of a person as a criterion for evaluating social relations. Nowadays the recognition of these rights also implies the struggle for them, which is reflected in the Belarusian Dictionary of Practical Psychologist, according to which humanism reflects the high level of conscious attitude of a human to other humans and is expressed in deep respect for a human and its dignity, the active struggle against all forms of misanthropy" .

\footnotetext{
${ }^{4}$ Гончаренко С.У. Український педагогічний словник. - К.: Либідь, 1997. - 376 с.

${ }^{5}$ Словарь практического психолога / Сост. С.Ю. Головин. - Минск: Харвест, 1998.
} 
In the World Encyclopedia ${ }^{6}$ „Humanism” is interpreted as a worldview of anthropocentrism, ,... which is permanently subject to comprehension and reflection in the canons of the value-based approaches of the Renaissance and later philosophical systems".

An overview of how humanistic thought has evolved in philosophy has already been made by us in the previous section, and this determination is valuable to our study given that the constant reflexive rethinking of „humanism” as a fundamental principle of pedagogical activity is a prerequisite for the highest self-sufficiency and selfawareness of a teacher.

In the Sociological Encyclopedic Dictionary ${ }^{7}$ an attempt was made to unify and systematize the world sociological terminology. Humanism is defined as ,an ideology and practice based on the principles of equality, justice, which regard a human as the highest value" and then as ,a direction in philosophy, science and art, which focuses on the internal and external qualities of a human and views it as ,a measure of all things". Both definitions are correct and reaffirm the thesis of the polyvariety of the notion of „humanism”, which is also determined by the possibility of defining its nature in the context of different cultures and civilizations, and taking into account the content of human values that each nation sees, preserves and reproduces in its own way. It is fundamentally important to address the content of these values in the context of the Ukrainian mentality.

Indeed, the evolution of the human race, human life, its rights and conditions of existence demand from it the self-realization of genetic and acquired potential. Therefore, every individual, improving its own kind, sometimes acts against its own interests for the benefit of the mankind, for the sake of its development and preservation as a biological species and conscious subject of historical processes.

In this regard, the fundamental human rights are highlighted, such as: the right to the human community, communication and personal freedom

\footnotetext{
${ }^{6}$ Всемирная энциклопедия: Философия / Главн. науч. ред. и сот. А.А. Грищанов. М.: АСТ, Мн.: Харвест, Современный литератор, 2001. - 1312 с.

${ }^{7}$ Социологический энциклопедический словарь. На русском, английском, немецком, французском и чешском языках. Редактор-координатор - академик РАН Г.В. Осипов. М.: Издательская группа ИНФРА М-НОРМА, 1998. - 488 с.
} 
and individuality; the right to work and private property; the right to knowledge and information; the right to creativity and to all-round development.

Thus, these human rights are universal human values that act as both a process and a result. The process is always the prerequisite for the result. In the context of our study, this process is defined as a process of humanization of pedagogical activity, which is, in essence, a struggle for the realization of the above-mentioned rights of a teacher and a child with the aim of their full harmonious development.

The Constitution of Ukraine (Article 3) establishes that «a person, its life and health, honor and dignity, integrity and security are recognized as the highest social value», which is a fundamental justification for the creation of humanely directed laws for the existence of Ukrainians.

The systemic changes covered in other regulatory documents regulate the activity of the educational branch of Ukraine, aimed at its humanization and democratization, methodological reorientation of the activity of a teacher of a higher education institution from training to the development of a student's personality, which actualizes at all levels the value of scientific researches related to clarification of the mission and meaning of the pedagogical activity on the principles of humanism.

In the Ukrainian Pedagogical Dictionary, the term ,humanization of education” is defined as ,the central component of a new pedagogical thinking, which involves the revision, reassessment of all components of pedagogical activity in the light of their human-creation function. Humanization of education means respect of an educational institution and teachers for the child's personality, credibility to it, acceptance of its personal goals, needs and interests; creation of the most favorable conditions for revealing and developing abilities and talents for its full life at each of the age stages, for its self-determination ${ }^{8}$.

In the context of new slogans, but with the old scientific and methodological support of the existence of a higher education institution, the proposals for radical changes in pedagogical activity and violation of stereotypes of long-term practice have always been accepted by teachers and scientists with caution. Moreover, there is no clear idea of HOW

\footnotetext{
${ }^{8}$ Гончаренко С.У. Український педагогічний словник. - К.: Либідь, 1997. - 376 с.
} 
(highlighted by the author) the teacher should "review and re-evaluate" his / her activity, making "humanism a central component of his / her thinking". One might assume that this is due to the fact that most researchers consider pedagogical activity to be a humanistic a priori, but educators know that this is not true in practice.

Therefore, in our hypothesis, in solving this problem, we should rely on the fundamental need of each teacher of higher education institutions in the independent realization of personal humanistic potential, by which we understand the totality of his/her internal forces aimed at respecting the dignity of each subject of pedagogical process, treating a student as the highest value on a par with himself/herself and other members of society.

In modern pedagogical psychology we have a number of criteria for the personal development and personal maturity of a teacher, and therefore indicators of his/her personal humanistic potential. In recent times, the "self-realization" has occupied a special place among such indicators. Undoubtedly, the «self-realization» is a conceptual construct established in philosophy, pedagogy and psychology. At the same time, the symmetry of reflection of the true nature of personality in it is a theoretical and methodological issue that will be debated for a long time. Average ideas and artistic expression of personality, observations and empirical facts indicate that a human, in one form or another, has always a desire for self-disclosure, for the realization of itself. With all the differences, the form of this process preserves the main thing - the need for self-realization of a human.

The phenomenon underlying the term ,self-realization" occupies a central place in the overall picture of the subjective world of a person, in the processes of personal development. The need for self-realization is inherent in every full person. Humanistic psychology and pedagogy recognized the desire of a human to become who he is as fundamental. The emphasis was on the fact that this quality is inherent in every person.

It is obvious that self-realization is a multidimensional phenomenon, differently directed, with different accents of its revealing. Our study focuses on the humanistic potential, which is the substance that ensures the preservation and development of each individual as a generic being in the full richness of its biological and social characteristics. The 
reproduction of these essential characteristics should simultaneously be the purpose, means and result of the teacher's functioning in his/her professional activity.

In the process of self-realization through the profession there are two aspects to be distinguished. On the one hand, this is the development of social space, expanding the sphere of influence and scale of social action, and on the other hand, increasing independence from the social environment, strengthening own autonomy.

There is no need to dive into the analysis of these aspects of selfrealization in order to see that the first of them is most clearly represented in the professional activity of a teacher of a higher education institution. Even in the ordinary mind the idea is fixed that the success of a teacher is largely determined by his/her purpose, i.e. the harmony of content plans and expression of pedagogical activity.

Based on the presented understanding of the main conceptual constructs of the study, let's move on to the next stage of clarification of the author's theoretical and methodological positions, namely the consideration of important tendencies in the professional activity of teachers of higher education institutions, which will influence the processes of humanization of their pedagogical activity.

\section{Trends and forecasts of characteristics of professional} and pedagogical activity of teachers of higher education institutions

In modern Ukrainian higher education, there are many familiar and well-established forms, methods and means of teaching activity, regulated by regulatory documents and supported in every way by the force of established traditions. Their creative, sometimes illegal, but evolutionarily inevitable interpenetration, merging and modification is a natural process of selecting the best options, determined by the changing tasks and goals of each particular university and teacher.

In this regard, it is a good practice to reflect on the future characteristics of higher education in Ukraine with the aim of creating a comfortable and thoughtful position in relation to a possible modification of the role, mission and functions of teachers of higher education institutions in the information society. The substantive basis of such reflections is some generalizations of the author's pedagogical 
experience in the framework of the training of teachers of higher education institutions at the Classic Private University.

The presentation of author's forecasts regarding some important trends in the professional activity of teachers of higher education institutions of the future on the basis of processes that are already manifested is an important task of the theory and methodology of their professional education.

The author's observations of the current situation in higher education allow to explicate a number of interesting contradictions that directly relate to our immediate future, in particular between:

- the teacher's traditionally steady desire to be the main reliable source of information for a student and growing technical capabilities, due to which his/her direct presence and contact are not always required;

- the permanent increase in the possibilities of an objective assessment of the quality of pedagogical work by means of a statistical analysis of feedback parameters (for example, thanks to lecture halls specially equipped with click-equipment, anonymous sites where each student can leave a comment about his/her own impressions of the teacher's work) and the lack of a valid mechanism for correlating teaching skills with salary;

- the abstract nature of the correlation of the results of pedagogical work with the economic benefits of scientific and pedagogical staff and specific readiness, business interest in knowledge, skills, values, attitudes and competencies of university graduates;

- the declaration in Bologna agreements of the need for a mobile, rich, mutually beneficial exchange of teachers in higher education institutions of the European Union and the lack of a real economic, and sometimes legal, ability to carry out a qualitative increase in their own professional qualifications in leading higher education institutions;

- an increase in the number of multimedia models of higher education in developed and developing countries, an increase in the educational role of electronic mass communication means and an imperfect legislative basis in this area, the lack of opportunity to quickly master this skill for all teachers of higher education institutions.

These and many other contradictions generate local energy for overcoming the crisis, in which there is not always a place for officially 
declared policy of higher education institutions, but there is always the opportunity to make a significant correction in the organization of the real pedagogical process. For example, many experts include the transfer of energy of pedagogical processes into the area of students' autonomous educational behavior, their independent work, in the trends already observed $^{9}$. With the aim, first of all, of saving, universities are trying to transform many types of students' educational work into an independent plane, using methodological platforms such as Moodle, etc. Their role in learning is gradually growing, crowding out not only expensive paper media, but also many "informative", low-activity types of classroom work. Indeed, is there any sense in the inefficient reading out of new information from a book, during which the teacher has not received a single question from the audience, has not reacted to an obvious loss of interest and a decrease in the level of information comprehensibility? It is more efficient to replace such a lecture by viewing better analogues, for example, Nobel laureates recorded on video using expensive demonstration equipment, 3D graphics, etc., isn't it? Given the growing mood to "save", such a decision will probably also come at the level of state standards, which means that over time, any student, regardless of country of residence, will be able to have access to the world's best teachers and scientists concerning any problem or discipline.

It is obvious that the war for the minds, feelings and attitudes of modern students is gradually moving into the Internet environment convenient, capacious, bright, comfortable. In fairness, it should be said that our students have long been "living" in it, and computer processors in various forms are gradually becoming an extension of their body, sensory organs and brain. This is what one of the most successful futurists of our time, Ray Kurzweil, spoke of when he foretold that by 2025-2030 a gradual merging of human organisms with powerful nanocomputers will begin, thanks to which our life would last indefinitely,

\footnotetext{
9 Солдатенко М.М. Теоретико-методологічні основи розвитку самостійної пізнавальної діяльності майбутнього вчителя : дис. ... д-ра пед. наук : 13.00 .04 / Солдатенко Микола Миколайович. - К., 2006. - 427 с.
} 
and most of the processes would be controlled by several grams of inanimate matter created by us and sometimes thinking for us ${ }^{10}$.

Clear for professionals, but still latent for the general public, the problem of saving expensive teaching time, amid the social, demographic and economic troubles going after our country since its inception, requires an immediate reaction and a well-considered solution. At the same time, the need to reduce the cost of the educational product by reducing the share of "manual labor" or its cost becomes natural, as does the replacement of a human in all types of industries where it is possible.

Presenting the results of our own research, most of which are interface between a not yet formed theory and a practice untested by a prolonged experiment, I would like to outline the essence of possible changes in the work of a teacher of a higher education institution in the context of globalization and computerization.

An important change concerns the mission of the classroom work of a teacher of a higher education institution. In the new conditions, it can be expressed in the following hypothesis: a successful teacher of a higher education institution in the 21 st century gradually change the style of classroom work from "informing" to "inducing", "advertising", "motivating", "inspiring". The main goal of this work will be the student's desire and ability to act independently. In private higher education institutions of the country, where financial support of the state is almost absent, and wealthy investors are in no hurry to invest in the future of the education sector this trend is becoming more noticeable, because in the conditions of high competition for survival and prosperity, Ukrainian universities in the last 8-10 years have been inviting people with limited time resources to study and rely on their independent work with a predominance of distance interaction.

It is likely that with the liberalization of the regulatory basis for the organization of the educational process, the rules of licensing and accreditation of specialties, with the transfer of the function of monitoring the results of the educational process to independent and

10 Predictions made by Ray Kurzweil [Electronic resource]. - Mode of access: http://en.wikipedia.org/wiki/Predictions_made_by_Ray_Kurzweil. 
objective professional communities, this decision will become the basis for a significant modernization of higher education.

Today, unfortunately, the category of people who are not professionally self-identified and only interested in obtaining a diploma of higher education and obtaining a formal right to occupy a position is growing and expanding. This phenomenon is peculiar not only to the Ukrainian mentality and is the subject of a separate discussion, but signs of a way out of this situation are already emerging. In this sense, market relations inevitably separate professionals and amateurs with diplomas. Today, in general, few people would think of hiring a person to provide any service, based only on the presence of his/her diploma. As to the survival of higher education institutions, given that in 1995-2001 the birth rate was permanently decreasing ${ }^{11}$, most likely a decision on the liberalization of state policy in the field of certification of specialists will be taken. Thus, many other extra-university factors will be involved, and higher education institutions interested in increasing the cost of a diploma will be forced to enter into a competitive struggle for the client offering an improved quality of education.

Under these conditions, in addition to the usual and well-established forms of academic work, the standards that confidently would have been impossible 20 years ago due to the lack of some technological resources and inexpensive but adequate material base confidently break into the standards of modern professional education.

Trends in the modification of the profession of a teacher of higher education institution, observed and understood on the basis of a real pedagogical experiment at the Classic Private University, allow at this stage of the experiment to confirm the hypothesis of the advisability of changing the "informative" teaching style to "inducing", "suggestive", "convincing", "advertising" or "inspiring".

This decision will allow most teachers to fit most comfortably into the already visible model of future higher education, in which a significant part of the work will be transferred to more intelligent, convenient and inexpensive machines and the main sought-after ability

11 Державна служба статистики України [Електронний ресурс]. - Режим доступу: http://www.ukrstat.gov.ua/ 
of the „classroom" teacher will be the ability to engage students of various specialties in prolonged self-study on the methodological basis of universities.

Thus, "lighting a fire" of the desire to study independently, with minimal effort and time in the classroom format advertise local resources to support curriculum, and then continue managing independent educational activity of students in distance format - this is a model of teaching that will be in demand in the future.

An important characteristic of such a future, following the logic of the universally dominant "Chinese" strategy for the production of material and ideal goods, will be the reduction in the cost of training. This is what will entail the high competitiveness of the "prompting" rather than the "informative" teaching style. Indeed, before our very eyes a whole galaxy of educating masters is born, who do not have, due to the prevailing economic inexpediency, the real empirical science behind, but have an "inspiring", "motivating" competence, which is capable to fulfill, on the basis of high emotional intelligence, personal charm and artistry, at least one task set by the leadership throughout the world to enroll and retain students in contractual relations with a higher education institution.

Thus, in the near future, according to our forecasts, a certain separation of forms of labor will occur. Some teachers - scientists will gain knowledge - others - will popularize and transfer it. This practice, based on healthy competition, has long existed in a world where at most one percent of the population creates technologies, standards and algorithms, while the remaining 99 percent use them, to our general educational joy, - yet in a creative way.

Returning to the experimental program for the training of future university teachers at the Classic Private University, in which most of the energy of the pedagogical process has been transferred to the remote format, at this time we can identify the following areas of greatest difficulties: a lack of prolonged personal contact with "knowledge holders", difficulties in acquiring the majority of non-thinking skills, and general lag of a specific professional-kinesthetic culture. I would like to highlight the main positive aspects: increased access to educational resources; involving people living in remote areas through the use of the 
Internet; manufacturability in assessing a significant part of the cognitive component of learning; minimum level of human-to-human violence; creation of a competitive environment for the emerging market of teachers of the «inspiring» genre. The last thesis, from the point of view of the development of the higher education system, is of great importance. As already mentioned at the beginning of the article, the teacher today is in a slightly competitive environment and is not formally directly interested in the results of his/her work. The increasing opportunities for a fair and accurate assessment of him/her through analysis of feedback from consumers of services allow to hope for the creation in the near future of a system of direct behavior-oriented reinforcement of the teacher's efforts in demonstrating pedagogical skills in classroom and some other work.

A content analysis of one of the most popular, although not perfect, web sites dedicated to creating a teacher rating can largely serve as an example of the vision of the future. The opinion of the consumers of educational services themselves - students of various specialties - allows to track the latent dynamics of satisfaction with various aspects of the pedagogical work of teachers of higher education institutions. At the same time, this can be done throughout almost the entire former Soviet Union. By the way, among the positive qualities that have recently dominated in the comments of students (and maybe teachers; the survey is anonymous), those that suggest the presence of the ability to optimistic, uplifting, supportive, facilitative teaching are leading:

"Very positive classes, after which I want to change something, not only in myself, but also in the world around us";

„Teacher is SUPER!!!!!!!!!!!! Cheers up in every class!!!»;

"Unforgettable classes, I sit with pleasure even at 8th-9th! And all because it's as if you are recharged with positive energy"12.

These and many other anonymous statements are of interest for analysis and introspection, which gives hope in general that the teaching profession will gradually approach higher competitiveness and measurability, which is of great importance in the era of market relations.

\footnotetext{
12 Рейтинг преподавателей [Электронный ресурс]. - Режим доступа: http://www.studzona.com/teacher.
} 
At this stage, the intensity with which students take notes is a significant problem. Unfortunately, it is not sufficient. Ideally, a teacher should be able to analyze the results of each class, which is quite possible if there are specially equipped classrooms in the "here and now" option, as well as to take into account the interests of other potential participants of the assessment of pedagogical work, namely:

potential employer and its goals, which may have significant contradictions with the existing theory and practice of professional training, standards of educational and qualification characteristics, etc.;

the head (owner) of the education institution, who pays the teacher a salary and is often interested in profit;

relatives of the student, who usually pay for his/her studying.

The popular political program Shuster-Live, in which you can see samples of future models of classroom work based on instant feedback, can be considered as the analogue of this technology in today's mass media.

Thus, the slow but steady changes taking place in the field of higher education make it possible to track some trends in the professional activity of teachers of higher education institutions at the local experimental level.

We are accustomed to the fact that teachers of higher education institutions can and should live and work for a long time. Their value in prolonged, active contact does not devalue over the years, and thoughts continue to fill the inner world of their students. The reason for the belief that this will always be the case lies in the characteristics of the profession. It is one of those few in which the person is charged with the duty of "mutual impregnation", mutual enrichment with feelings, thoughts and actions of another person. At that, the value of such a direct human contact „teacher-student" inevitably grows. In improving the technique of such ,mutual impregnation” as a component of pedagogical mastery, it is very important to avoid cliches, to form the own style of using all expressive means using which a teacher achieves originality and targeted influence. Nevertheless, the steady technological progress leads to some useful generalizations regarding the teaching work that will be in demand in the near future.: 
- the degree of saturation of interpersonal contacts ,teacher-student” will fall, which will cause the need to shift emphasis of classroom work from the ,informing” genre to the „facilitative”, ,inspiring”, „motivating" one;

- the transfer of the energy of academic work to the plane of the sphere of students' personal responsibility determines the need to develop, without exception, specific teachers' skills in servicing and supporting this work in the area of autonomous behavior ${ }^{13}$;

- the automatic analysis of feedback signals, along with thoughtful control and monitoring of the cognitive, emotional and behavioral areas of future specialists, will put the teacher in a severe but fair competition in the labor market.

This idea, in fact, is part of the formulation of the problem of vision of the future ideal Ukrainian university and a Ukrainian teacher. It does not pretend in any way to objectivity and accuracy in the assumptions made, but allow to better understand and determine in which higher education system we will have to work soon.

\section{SUMMARY}

The problem of ensuring humanization of pedagogical activity of teachers of higher education institutions is considered in the section. It was shown that its solution has a positive effect in solving many existing educational problems: establishing communication between the subjects of the pedagogical process, eliminating the leveling of social, religious, national inequality, protection of the rights of the teacher, etc.. It was proved that this approach resists the manipulative effects of the technologized world, which were destructive for a teacher, - electronic communication, suggestive, psychotropic, etc., but one had to admit that in the mass practice of modern professional education its implementation had not achieved significant success.

The section presents the understanding of the main conceptual constructs of the research and provides a prognostic analysis of

13 Солдатенко М.М. Теоретико-методологічні основи розвитку самостійної пізнавальної діяльності майбутнього вчителя : дис. ... д-ра пед. наук : 13.00 .04 / Солдатенко Микола Миколайович. - К., 2006. - 427 с. 
important tendencies in the professional activity of teachers of higher education institutions, which will influence the processes of humanization of their pedagogical activity.

\section{REFERENCES}

1. Predictions made by Ray Kurzweil [Electronic resource]. - Mode of access: http://en.wikipedia.org/wiki/Predictions_made_by_Ray_Kurzweil.

2. Всемирная энциклопедия: Философия / Главн. науч. ред. и сот. А.А. Грищанов. - М.: АСТ, Мн.: Харвест, Современный литератор, 2001. - 1312 с.

3. Гончаренко С.У. Український педагогічний словник. - К.: Либідь, 1997. - 376 с.

4. Гордон Д. Революція в навчанні / Гордон Драйден, Джанетт Вос ; пер. $з$ англ. М. Олійник. - Л. : Літопис, 2005. - 542 с.

5. Державна служба статистики України [Електронний ресурс]. - Режим доступу: http://www.ukrstat.gov.ua/

6. Закон України «Про Вищу освіту» https://zakon.rada.gov.ua/ laws/show/1556-18

7. Закон України «Про освіту». Відомості Верховної Ради (BBP). 2017. № 38-39. c. 380. https://zakon.rada.gov.ua/laws/show/ 2145-19

8. Концепції реалізації державної політики у сфері реформування загальної середньої освіти «Нова українська школа» на період до 2029 року [Електронний ресурс]. - Режим доступу: https://zakon.rada.gov.ua/laws/show/988-2016-\%D1\%80/stru

9. Національній стратегії розвитку освіти в Україні на період до 2021 року [Електронний ресурс]. - Режим доступу: https://zakon2.rada.gov.ua/laws/show/344/2013/page

10. Рейтинг преподавателей [Электронный ресурс]. - Режим доступа: http://www.studzona.com/teacher.

11.Словарь практического психолога / Сост. С.Ю. Головин. Минск: Харвест, 1998.

12. Солдатенко М.М. Теоретико-методологічні основи розвитку самостійної пізнавальної діяльності майбутнього вчителя : дис. ... д-ра пед. наук : 13.00.04 / Солдатенко Микола Миколайович. - К., 2006. -427 c. 
13.Социологический энциклопедический словарь. На русском, английском, немецком, французском и чешском языках. Редакторкоординатор - академик РАН Г.В. Осипов. - М.: Издательская группа ИНФРА М-НОРМА, 1998. - 488 c.

\section{Information about the author: Sushchenko A. V.,} Doctor of Science in Professional Education, Professor, Head of the Department, Professor of the Education and Management of Educational Institution, Classical Private University 70b, Zhukovskoho str., Zaporizhia, 69002, Ukraine

\section{Dariush Skalski,}

Doctor of Pedagogical Sciences, Research and Education Officer, Instructor-Lecturer (WORP), Water Rescue Instructor, Academy of Physical Education and Sport Gdańsk, Poland 